\title{
Synthesis of Enzymatically Active Firefly Luciferase in Yeast
}

\author{
Hiroki Tatsumi, Tsutomu Masuda and Eiichi NaKano \\ Research and Development Division, Kikkoman Corporation, \\ 399 Noda, Noda-shi, Chiba 278, Japan \\ Received October 16, 1987
}

\begin{abstract}
A recombinant plasmid containing a DNA segment complementary to the mRNA of the North American firefly, Photinus pyralis, luciferase was constructed and cloned into Escherichia coli. The cDNA was inserted into a yeast expression vector, AAH5, designed to express active luciferase under the control of the yeast alcohol dehydrogenase promoter. When introduced into the yeast, Saccharomyces cerevisiae, the resultant plasmid directed the synthesis of enzymatically active firefly luciferase, the activity of which was inhibited by antiserum raised against the purified firefly luciferase.
\end{abstract}

Firefly luciferase from Photinus pyralis catalyzes the oxidative reaction of luciferin in the presence of ATP and $\mathrm{O}_{2} \cdot{ }^{1)}$ Due to its high sensitivity and specificity, the firefly luciferase assay is used widely for the measurement of ATP in biological samples. ${ }^{2)}$ Many nucleotides and enzymes can be measured sensitively through coupling with a reaction that produces ATP. An enzyme immunoassay involving luciferase has also been developed. ${ }^{2,3)}$

Nowadays, recombinant DNA technology allows the cloning and expression of a DNA fragment which codes for a mammalian protein in microorganisms. Recently, firefly luciferase cDNA was isolated and expressed in $E$. coli ${ }^{4)}$ mammalian cells ${ }^{5)}$ and plant cells. ${ }^{6)}$

We report here the cloning of firefly luciferase cDNA, from desiccated firefly tails, and the expression of the active firefly luciferase in yeast.

\section{MATERIALS AND METHODS}

Strains and transformation procedures. E. coli strain DH $1\left[\mathrm{~F}^{-}\right.$recAl endAl gyrA96 thi-1 hsdRI7 $\left(\mathrm{r}_{\mathrm{k}}{ }^{-} \mathrm{m}_{\mathrm{k}}{ }^{-}\right)$ supE44 $\lambda^{-}$] was used as a carrier for recombinant plasmids. The yeast, Saccharomyces cerevisiae strain SHY ${ }^{7}{ }^{71}$ was obtained from Prof. Akio Toh-e of Hiroshima University. The transformation of $E$. coli and yeast was carried out by the methods of Hanahan $^{87}$ and Beggs, ${ }^{9}$ respectively.
Plasmids. Plasmid pMCE10 was obtained from $\mathrm{Mr}$. Asahi Matsuyama of Kikkoman Corporation. Plasmid pUC19 was purchased from Takara Syuzo. The yeast alcohol dehydrogenase promoter vector, AAH $5,{ }^{10)}$ was obtained from the Washington Research Foundation. Plasmids were prepared as previously described. ${ }^{11}$

Materials. The materials were obtained from the following sources: radiochemicals, the rabbit reticulocyte lysate and the cDNA synthesis kit from Amersham; oligo(dT)cellulose and the ribonucleoside vanadyl complex from New England Biolabs; protein A-Sepharose 4B from Pharmacia; and desiccated firefly tails from Sigma Chemical Company.

All restriction enzymes and T4 DNA ligase were purchased from either New England Biolabs or Takara Shuzo, and were used as recommended by the respective suppliers.

Antiluciferase antiserum production was induced in white rabbits by injection of the purified luciferase $(2.3 \mathrm{mg})$ emulsified in complete Freund's adjuvant. After two boosters with $2.3 \mathrm{mg}$ of luciferase, the antiserum was collected.

Preparation and purification of $m R N A$. Desiccated firefly tails were ground in a mortar, and then 5 volumes of $20 \mathrm{~mm}$ Tris buffer, $\mathrm{pH} 7.4$, containing $10 \mathrm{~mm} \mathrm{NaCl}, 3 \mathrm{~mm}$ $\mathrm{Mg}\left(\mathrm{CH}_{3} \mathrm{COO}\right)_{2}, 5 \%$ sucrose, $1.2 \%$ Triton $\mathrm{X}-100$ and $10 \mathrm{~mm}$ ribonucleoside vanadyl complex was added to dissolve RNA. This suspension was homogenized in a Waring Blender with 2.5 volumes of $37.5 \mathrm{~mm}$ sodium citrate buffer, $\mathrm{pH} 7.0$, containing $6 \mathrm{M}$ guanidine isothiocyanate $0.5 \%$ Sarkosyl and $0.15 \mathrm{M} \beta$-mercaptoethanol. The resulting homogenate was layered onto a $1.2-\mathrm{ml}$ cushion of $5.7 \mathrm{M} \mathrm{CsCl}$ in $0.1 \mathrm{M}$ EDTA, pH 7.5, in a Hitachi 
S55Ti rotor. Centrifugation was carried out for $16 \mathrm{hrs}$ at $30,000 \mathrm{rpm}$ at $15^{\circ} \mathrm{C}$. The pellet of RNA was dissolved in a minimum volume of $10 \mathrm{~mm}$ Tris buffer, pH 7.4, containing $5 \mathrm{mM}$ EDTA and $1 \% \mathrm{SDS}$, and then extracted with an equal volume of a $4: 1$ mixture of chloroform and 1butanol. The lower layer was removed and re-extracted with $10 \mathrm{~mm}$ Tris buffer, $\mathrm{pH} 7.4$, containing $5 \mathrm{~mm}$ EDTA and $1 \%$ SDS. The two aqueous layers were combined and then RNA was precipitated twice with ethanol.

Poly $(\dot{A})^{+}$RNA was separated from rRNA by chromatography on oligo(dT)-cellulose. ${ }^{12)}$

The concentration and cell-free translation of luciferase mRNA were carried out as previously described. ${ }^{13)}$

Synthesis and cloning of luciferase cDNA. CDNA was synthesized using the Amersham cDNA synthesis kit. The addition of homopolymer $\mathrm{dC}$ or $\mathrm{dG}$ tails to the $3^{\prime}-\mathrm{OH}$ ends of DNA and the annealing were performed as previously described. ${ }^{14}$ Labeling of a DNA fragment with ${ }^{32} \mathrm{P}$ and colony hybridization were carried out as previously described. ${ }^{13)}$

Expression of the luciferase gene in yeast. Yeast strain SHY1 containing pALf3 was grown at $30^{\circ} \mathrm{C}$ to 200 Klett units at $660 \mathrm{~nm}$ in YPD medium. ${ }^{15}$ ) One volume of the culture was centrifuged and the resultant cell pellet was suspended in a $1 / 5$ volume of $100 \mathrm{~mm}$ potassium phosphate buffer, pH 7.8, containing $2 \mathrm{~mm}$ EDTA, $1 \mathrm{mM}$ dithiothreitol and protamine sulfate at $0.2 \mathrm{mg} / \mathrm{ml} .{ }^{16)}$ Glass beads were added to the suspension, followed by stirring with a vortex mixer to destroy yeast cells, and the lysate obtained was cleared by centrifugation.

The luciferase activity in the yeast extract was assayed

A

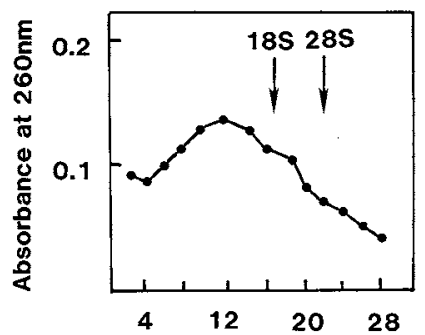

by the method of Kricka and DeLuca. ${ }^{17}$ The inhibition of the luciferase activity by the antiluciferase antibody was measured as follows. The yeast extract was mixed with bovine serum albumin (BSA), phenylmethylsulfonyl fuoride (PMSF) and antiluciferase serum; the final concentrations and dilution being $1 \mathrm{mg} / \mathrm{ml}, 2 \mathrm{~mm}$ and $1: 100$, respectively. The extract was incubated overnight at $4^{\circ} \mathrm{C}$ and then assayed for luciferase activity.

\section{RESULTS AND DISCUSSION}

\section{Preparation and purification of firefly luciferase $m R N A$}

Total cellular RNA was extracted from desiccated firefly tails and the poly(A)-containing RNA was separated using oligo(dT)-cellulose. The poly $(\mathrm{A})^{+}$RNA was fractionated as to size on a 10 to $25 \%$ sucrose gradient and then the luciferase-mRNA-enriched fractions were localized by means of the cell-free translation assay coupled with specific immunoprecipitation. Luciferase mRNA was found in the $18 \mathrm{~S}$ region of the gradient (Fraction No. 17 in Fig. 1).

\section{Cloning of firefly luciferase $c D N A$}

Double-stranded cDNA was synthesized from partially purified luciferase mRNA and inserted into the AccI site of plasmid pMCE10

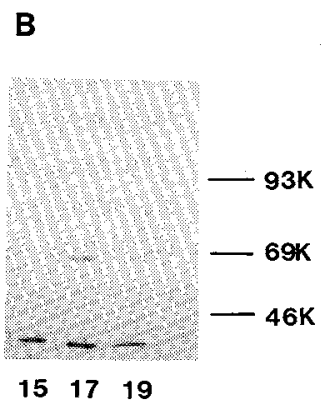

Fraction Number

Fig. 1. Sedimentation Profile of Firefly Lantern Poly(A) ${ }^{+}$RNA on Sucrose Density Gradient Centrifugation.

(A) Poly(A) ${ }^{+}$RNA extracted from firefly tails was layered on a sucrose density gradient. Sedimentation markers, firefly $18 \mathrm{~S}$ and $28 \mathrm{~S}$ rRNA, were run on a parallel gradient.

(B) Aliquots of the indicated fractions were translated in a rabbit reticulocyte lysate system containing $\left[{ }^{35}\right.$ S]methionine. The labeled products were analyzed by immunoprecipitation and electrophoresis on a $7.5 \%$ SDS-polyacrylamide gel. The molecular weight of American firefiy luciferase has been reported to be $61,000 .^{5}$ The molecular weight markers were $\left[{ }^{14} \mathrm{C}\right]$ methylated phosphorylase $(93,000)$, bovine serum albumin $(69,000)$ and ovalbumin $(46,000)$. 
by the oligo $(\mathrm{dC})$-oligo(dG) annealing procedure and then used to transform $E$. coli DH1.

As shown in Fig. 2, pMCE10 is the plasmid that $E$. coli $\beta$-galactosidase structural gene of pMC1403 ${ }^{18)}$ was inserted into the tryptophan promoter vector, pKN306. ${ }^{11)}$ Expression of the $\beta$-galactosidase gene carried on plasmid pMCE10 is under the control of the trp promoter. As the $A c c$ I site lays in the $\beta$-galactosidase structural gene, a protein encoded by inserted DNA at this site can be expressed as a protein fused to $E$. coli $\beta$-galactosidase.

We identified a luciferase cDNA clone on immunoblotting. Proteins prepared from a pool of 96 transformants were separated by SDS-polyacrylamide gel electrophoresis (PAGE) and transferred to a nitrocellulose filter, and then the nitrocellulose filter was probed with antiluciferase antibody. Two out

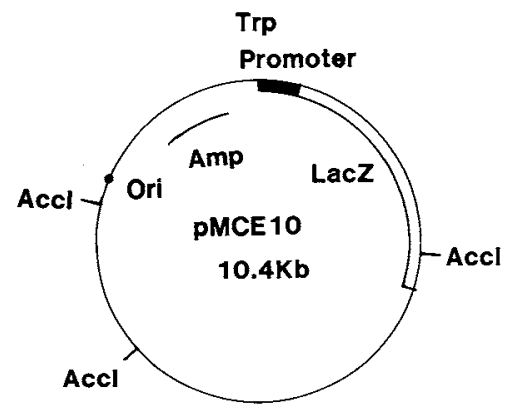

FIG. 2. Structure of Plasmid pMCE10.

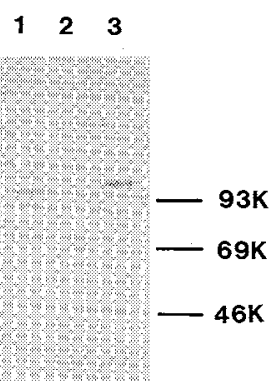

FIG. 3. Detection of a lacZ-Luciferase Fusion Protein in E. coli Cells.

Proteins extracted from $E$. coli $\mathrm{DH} 1$ containing pALf2B8 (lane 1), pMCE10 (lane 2) and pALf3A6 (lane 3) were separated on a $7.5 \%$ SDS polyacrylamide gel, respectively, and then subjected to immunoblot analysis as described under Materials AND METHODS. of 4 pools of 96 clones gave positive results in this assay. The bacterial clones in the two positive groups were arranged into 8 subgroups of 12 clones, respectively, and assayed as above. The two positive subgroups were respectively divided into 12 individual clones and then assayed as above. Two positive clones were identified (Fig. 3). Fusion proteins, between $\beta$-galactosidase and luciferase, are observed in lanes 1 and 3, whose molecular weights were estimated to be about 100,000 and 110,000 , respectively. The plasmids in these bacterial clones were designated as pALf2B 8 and pALf3A6, respectively.

pALf3A6 contained a 500 base-pairs cDNA encoding a part of the firefly luciferase protein. To obtain a larger cDNA, a firefly lantern cDNA bank was screened by means of colony hybridization using ${ }^{32}$ P-labeled luciferase cDNA of pALf3A6 as a probe. The cDNA bank was constructed by inserting the cDNA into the Pst I site of pUC19 and then transfoming it into $E$. coli $\mathrm{DH} 1$.

A plasmid, pALf3 (Fig. 4), containing a 1700-base pairs insert was isolated. de Wet et al. recently determined the complete nucleotide sequence of firefly luciferase cDNA. ${ }^{5}$ The cutting sites for restriction endonucleases of luciferase cDNA prepared in the present study are completely coincident with those predicted from the nucleotide sequence reported by de Wet et al. The sequence comparison, however, revealed that our cDNA lacks the 5'-non-coding region and a part of coding region which specify about $10 \mathrm{NH}_{2}{ }^{-}$ terminal amino acids of the 550 amino acids sequence of luciferase.

\section{Expression of firefly luciferase in yeast}

Figure 4 shows the procedure for the construction of a plasmid that allows expression of the firefly luciferase gene in yeast. Plasmid pALf 3 was cleaved with $B a m H I$ and $X b a I$. The $X b a I$ site lays in the luciferase cDNA coding for amino acid 17 from the $\mathrm{NH}_{2}$-terminus. An ATG translation initiation codon was attached to this $X b a I$ site using synthetic oligonucle- 


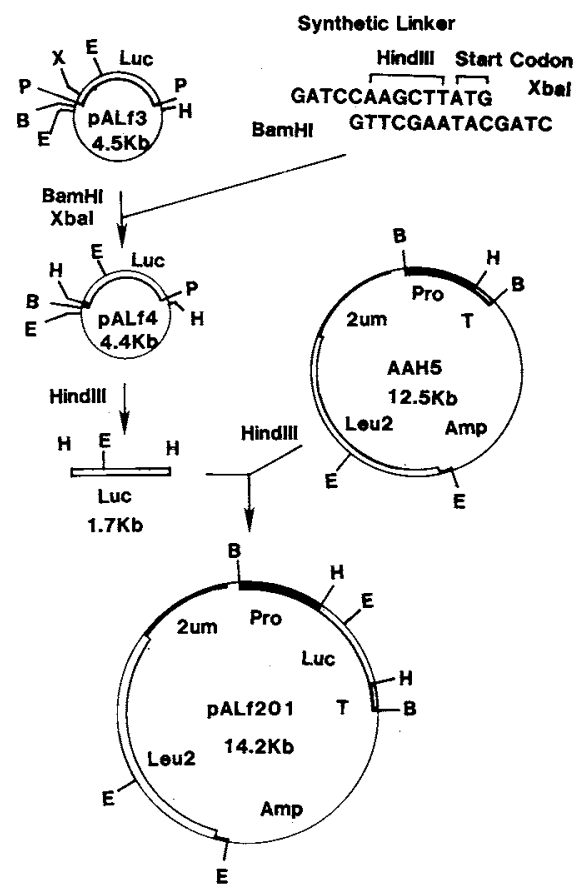

FIG. 4. Construction of pALf201.

pALf4 was constructed by inserting a synthetic linker between the $X b a I$ site and the BamHI site of pALf3. The $H$ indIII fragment containing the luciferase gene was recovered from pALf4 and subcloned into the HindIII site of the yeast expression vector, AAH5, yielding pALf201. Abbreviations: Luc, luciferase gene; Pro, ADHI promoter; T, ADHI terminator; B, BamHI; E, Eco RI; H, HindIII; P, Pst I; X, XbaI.

otides. This luciferase gene was cloned into the HindIII site of yeast expression plasmid AAH5, yielding pALf201, the expression of the firefly gene being under the control of the yeast alcohol dehydrogenase promoter. ${ }^{10}$ ).

Plasmid pALf201 was introduced into yeast strain, SHY1, by transformation. Extracts from the yeast bearing pALf201 were examined for luciferase activity. The production of light was detected in the presence of ATP and luciferin, as shown in Table I. The production of light was not detected when extracts from the yeast bearing vector plasmid AAH5 were used. The amount of light detected corresponded to about $10 \mathrm{ng}$ of luciferase per $1 \mathrm{ml}$ culture. The luciferase activity appearing in the yeast was completely inhibited by the antiluciferase antibody (Table I). These
Table I. Number of Photons Emitted by the Luciferase Produced in Yeast

\begin{tabular}{lcc}
\hline & $\begin{array}{c}\text { Addition } \\
\text { of antiserum }\end{array}$ & $\begin{array}{c}\text { Number of } \\
\text { photons }\end{array}$ \\
\hline Purified luciferase & - & $2.4 \times 10^{7 a}$ \\
pALf201/SHY1 & - & $3.7 \times 10^{5 b}$ \\
pALf201/SHY1 & + & $1.3 \times 10^{4 b}$ \\
AAH5/SHY1 & - & $1.6 \times 10^{4 b}$ \\
\hline
\end{tabular}

a Photon number per $780 \mathrm{ng}$ of purified luciferase.

$b$ Photon number per $\mathrm{ml}$ of culture.

data indicate that enzymatically active firefly luciferase was produced in the yeast.

In the present study, we constructed pALf201 in an attempt to obtain a sufficient quantity of firefly luciferase in yeast. Indeed active luciferase was expressed in the yeast but the level of expression in the yeast $(10 \mathrm{ng} / \mathrm{ml})$ was less than that in $E$. coli $\left(60 \mathrm{ng} / \mathrm{ml}^{4}\right)$. The level of expression of a foreign gene in yeast depends on the strength of the promoter. High level expression was achieved by using the glyceraldehyde-3-phosphate dehydrogenase gene promoter ${ }^{19)}$ and the phosphoglycerate kinase gene promoter. $^{20}$ ) Using these promoters, we might be able to increase the level of expression of luciferase in yeast.

The cDNA cloned in the study, which crosshybridizes with Japanese firefly, Luciola cruciata, luciferase mRNA, will be a valuable probe for cloning the Japanese firefly luciferase cDNA.

Acknowledgments. We wish to thank Professor Akio Toh-e for the generous gift of yeast strain SHY1, Mr. Asahi Matsuyama for the gift of pMCE10, and $\mathrm{Mr}$. Yasuhiko Nakajima for preparation of the antiluciferase antiserum. We also wish to thank Mrs. Kazuko Saitoh for her technical assistance.

\section{REFERENCES}

1) M. DeLuca and W. D. McElroy, Meth. Enzymol., 57, 3 (1978).

2) A. Lundin, in "Bioluminescence and Chemiluminescence. Basic Chemistry and Analytical Applications," ed. by M. A. DeLuca and W. D. McElroy, Academic Press, New York, 1981, pp. $187 \sim 196$. 
3) A. K. Campbell, TIBS, 11, 104 (1986).

4) J. R. de Wet, K. V. Wood, D. R. Helinski and M. DeLuca, Proc. Natl. Acad. Sci. U.S.A., 82, 7870 (1985).

5) J. R. de Wet, K. V. Wood, M. DeLuca, D. R. Helinski and S. H. Subramani, Mol. Cell. Biol., 7, 725 (1987).

6) D. W. Ow, K. V. Wood, M. DeLuca, J. R. de Wet, D. R. Helinski and S. H. Howell, Science, 234, 856 (1986).

7) D. Botostein, S. Carlfalco, S. E. Stewart, M. Brennan, S. Schere, D. T. Stinchcomb, K. Struhl and R. W. Davis, Gene, 8, 17 (1979).

8) D. Hanahan, in "DNA Cloning," Vol. 1, ed. by D. M. Glover, IRL Press, Oxford, England, 1985, pp. $109 \sim 135$.

9) J. D. Beggs, Nature, 275, 104 (1978).

10) G. Ammerer, Meth. Enzymol., 101, 192 (1983).

11) T. Masuda, E. Nakano, S. Hirose and K. Murakami, Agric. Biol. Chem., 50, 271 (1986).

12) T. Maniatis, E. F. Fritsch and J. Sambrook,
"Molecular Cloning. A Laboratory Manual," Cold Spring Harbor Laboratory, Cold Spring Harbor, N. Y., 1982, pp. $197 \sim 198$.

13) T. Fukushi, T. Masuda, T. Imai, M. Sudoh, S. Kimura, S. Hirose and K. Murakami, Biomed. Res., 3, 534 (1982).

14) T. Masuda, T. Fukushi, T. Imai, M. Sudoh, S. Hirose and K. Murakami, Biomed. Res., 3, 541 (1982).

15) H. Araki, A. Jearnpipatkul, H. Tatsumi, T. Sakurai, K. Ushio, T. Muta and Y. Oshima, J. Mol. Biol., 182, 191 (1985).

16) J. R. de Wet, K. V. Wood, D. R. Helinski and M. DeLuca, Meth. Enzymol., 133, 3 (1986).

17) L. J. Kricka and M. DeLuca, Arch. Biochem. Biophys., 217, 674 (1982).

18) M. J. Casadaban, A. Martinez-Arias, S. K. Shapira and J. Chou, Meth. Enzymol., 100, 293 (1983).

19) G. A. Bitter and K. M. Egan, Gene, 32, 263 (1984).

20) J. Mellor, M. J. Dobson, N. A. Roberts, A. J. Kingsman and S. M. Kingsman, Gene, 33, 215 (1985). 